\title{
Effect of irrigation intervals and foliar spray of zinc and silicon treatments on maize growth and yield components of maize
}

\author{
A. Abdelgalil ${ }^{a}$, A.A. Mustafa ${ }^{a}$, S. A. M. Ali ${ }^{\text {b and Omar M. Yassin }}{ }^{b^{*}}$
}

${ }^{a}$ Soil and water Department, Faculty of Agriculture, Sohag University, Egypt

${ }^{b}$ Soils, Water, and Environment Research Institute, Agricultural Research Center, Giza, Egypt

\begin{tabular}{l}
\hline C H R O N I C L E \\
\hline Article history: \\
Received June 29, 2021 \\
Received in revised form \\
July 20, 2021 \\
Accepted December 21, 2021 \\
Available online \\
December 21, 2021 \\
\hline Keywords: \\
Maize \\
Zinc \\
Silicon \\
Foliar \\
Grain yield
\end{tabular}
\begin{abstract}
A B S T R A C T
Field experiments were carried out for two consecutive seasons at the Experimental Shandaweel Agricultural Research Station, Sohag Governorate, Upper Egypt, during the growing seasons of 2013 and 2014, to study the Effect of Irrigation intervals and foliar spray of zinc and silicon treatments on Maize growth and yield components of maize. Results indicated that, scheduling at every 10 days produced the highest plant height, Flag Leaf area $\left(\mathrm{cm}^{2}\right)$, Cob length $(\mathrm{cm})$, Weight of 100-grains (g), Biological yield (T/fad.) and Grain yield (ard./fed.) followed by irrigation at 15 and 20 days interval, in contrast irrigation at 25 days interval produced the lowest values and foliar spray of zinc and silicon treatments produced the highest plant height-improved yield and yield components of maize crop. The best yield was obtained from zinc + silicon treatments followed by zinc, silicon treatments. In contrast, untreated treatments produced the lowest values. It can be concluded that the scheduling at every 10 days and application of foliar spray of zinc + silicon treatments as the effective one could be recommended for scheduling irrigation at every 10 days with application of foliar spray of zinc + silicon treatments of maize crop at Shandaweel Agricultural Research Station, Sohag Governorate, Upper Egypt to obtained the best results from maize grain yield.
\end{abstract}

\section{Introduction}

Recently, there is a great interest in scientific research that focuses on environmental and agricultural uses of functionalised organic and inorganic compounds. ${ }^{1-18}$ In Egypt, maize is a major cereal summer crop and it has a special importance because the national production is not enough to meet the increase of local demands. Egypt produces about 5.8 million tons of white maize and 1.3 million tons of yellow maize annually. ${ }^{19}$ While the domestic consumption was about 17.7 million tons. The amount of imports was about 10.8 in $2014 .{ }^{20}$ Egypt's prosperity still depends largely on the agricultural sector and its productivity. Egypt has a fixed share from the Nile Water (55.5 billion cubic meters). Capita share from water is less than 1000 cubic meters per year which is the water poverty limit. In Egypt Agriculture consumes more than $80 \%$ from the water reserves. Proper irrigation management leads to maximizing net return, minimizing irrigation costs, maximizing yield, optimally distributing a limited water supply and minimizing groundwater pollution. Irrigation water management or scheduling is a decision-making process to determine when and how much water to apply to a growing crop to meet specific management objectives. ${ }^{21}$ Zinc is most crucial amongst the micronutrients that take part in plant growth and development due to its catalytic action in metabolism of almost all crops. ${ }^{22}$ a critical small concentration of zinc is needed to perform several key pathways in plants. ${ }^{23}$ The level of zinc nutrition may affect plant water relations and alter stomatal conductance. ${ }^{24}$ Zinc deficiency may limit the ability of the crop to use the moisture reserves in the soil. ${ }^{25}$ Zinc deficiency affects the absorption of water and nutrients from soil and thus resulting in growth and yield reduction in the plant. $^{26}$

* Corresponding author.

E-mail address: omar66004510@gmail.com (O. M. Yassin)

(C) 2022 by the authors; licensee Growing Science, Canada doi: $10.5267 /$ j.ccl.2021.12.002 
Silicon nutrition has several beneficial effects on plant growth largely due to its unique physiological role. ${ }^{27}$ Observed that silicon fertilization affects stomatal conductance by adjustment of tissue water status but not through any physical modification. ${ }^{28}$ In this way drought might be proposed that silicon nutrition assists water uptake and its transportation to stem and leaves. Silicon application improves the water relation in plants. ${ }^{29}$ Reported that silica-cuticle double layer formed on leaf epidermis is liable for this improved water potential. ${ }^{30}$ Hence, suggesting an induction of drought tolerance by $\mathrm{Si}$ due to reducing transpiration loss of water under moisture stress condition.

\section{Results and Discussion}

\subsection{Maize growth and its yield}

\subsubsection{Plant height}

Data of maize plant height were presented in Table (1) regarding to irrigation treatments, the data stated that values of irrigation scheduling at 10,15 and 20 days increased this characteristic significantly by $12.9 \%, 8.2 \%$ and $5.2 \%$ in 2013 season and by $10.9 \%, 8.1 \%$ and $5.3 \%$ in the second season, as compared to irrigation every 25 days, respectively. These results may be due to the increase of available soil moisture in the short irrigation interval which enhanced cell division and stem cell elongation than long irrigation interval; in which increasing soil moisture stress decreased the relative growth rate. These results are in agreement with that finding. ${ }^{31-33}$

Significant differences were obtained in plant height due to spraying of zinc and silicon during the 2013 and 2014 summer seasons. Concerning the effect of zinc and silicon treatments on maize plant height. The tabulated data showed clearly that zinc and silicon treatments enhanced significantly values of this characteristic. Use of foliar spray of zinc, silicon and zinc and silicon treatments led to an increase in this characteristic by $4.11 \%, 8.69 \%$ and $13.12 \%$ in first season and by $3.89 \%, 9.22 \%$ and $12.76 \%$ in the second season as compared to non-treated treatment, respectively. ${ }^{34,35}$ They found that zinc and silicon application significantly increased the plant height of Maize. These results may be due to the positive effect of silicon and zinc treatments on Maize growth. Silicon nutrition has several beneficial effects on plant growth largely due to its unique physiological role. ${ }^{27}$

Results of interaction effect between irrigation intervals and foliar spray of zinc and silicon treatments on maize plant height. The effect of interaction on this characteristic was significant in the two studied seasons. The data showed that increasing water availability through irrigation increased the effect of foliar spray of zinc and silicon treatments. This might be attributed to the effect of available water on the transport process in higher plants.

\subsubsection{Flag Leaf area $\left(\mathrm{cm}^{2}\right)$}

At a first glance, the data stated in Table (1) that irrigation scheduling treatments significantly affected the values of this characteristic. Irrigation scheduling at every 10, 15 and 20 days increased flag leaf area of maize plants $\left(\mathrm{cm}^{2}\right)$ significantly by $60.4 \%, 23.2 \%$ and $9.8 \%$ in 2013 season and by $60.9 \%, 57.7 \%$ and 8.9 in the second season as compared to irrigation scheduling at every 25 days, respectively. The increase in the flag leaf area $\left(\mathrm{cm}^{2}\right)$ may be due to increasing in water supply that enhances the vegetative growth photosynthetic accumulation and metabolic activities in maize plant tissues. ${ }^{36}$

Regarding the effect of zinc and silicon treatments values of flag leaf area $\left(\mathrm{cm}^{2}\right)$, foliar spray of zinc and silicon treatments led to a significant increase in this characteristic by $14.5 \%, 8.9 \%$ and $21.4 \%$ in 2013 season and by $12.8 \%$, $11.25 \%$ and $20.3 \%$ in the second season, as compared to untreated treatments, respectively. This result is in agreement with that obtained. ${ }^{37,38}$

Results of interaction effect between irrigation intervals and foliar spray of zinc and silicon treatments on Maize flag leaf area. The effect of interaction on this characteristic was significant in the two studied seasons.

\subsubsection{Cob length (cm)}

The data stated in Table 1 that the average values of cob length $(\mathrm{cm})$ of irrigation scheduling at every 10,15 and 20 days significantly increased by $24.7 \%, 16.57 \%$ and $13.56 \%$ in 2013 season and by $34.2 \%, 25.7 \%$ and $10.9 \%$ in the second season, as compared to irrigation scheduling at every 25 days respectively. This might be attributed to positive effect of more available soil moisture on number of cells cell enlargement and turgidity and consequently cell size. ${ }^{39,40}$

The effect of foliar spray of zinc and silicon led to a significant increase in this characteristic by $4.9 \%, 0.84 \%$ and $11.4 \%$ in 2013 season and by $15.9 \%, 7.7 \%$ and $6.8 \%$ in the second season as compared to control treatment respectively. These results agree with that recorded. ${ }^{41,42,34}$ 
Table 1. Means of Plant height, Flag Leaf area $\left(\mathrm{cm}^{2}\right)$ and Cob length $(\mathrm{cm})$ of maize crop as affected by irrigation scheduling and foliar spray of zinc and silicon treatments for two growing seasons of 2013 and 2014.

\begin{tabular}{|c|c|c|c|c|c|c|}
\hline \multirow{2}{*}{ Treatments } & \multicolumn{2}{|c|}{ Plant height $(\mathrm{cm})$} & \multicolumn{2}{|c|}{ Flag Leaf area $\left(\mathrm{cm}^{2}\right)$} & \multicolumn{2}{|c|}{ Cob length $(\mathrm{cm})$} \\
\hline & 2013 & 2014 & 2013 & 2014 & 2013 & 2014 \\
\hline \multicolumn{7}{|c|}{ Irrigation scheduling (I) } \\
\hline $\mathrm{I}_{1}$ & 231.4 & 243.3 & 873.4 & 766.1 & 22.3 & 24.3 \\
\hline $\mathrm{I}_{2}$ & 221.7 & 237.9 & 670.9 & 751.0 & 20.8 & 22.8 \\
\hline $\mathrm{I}_{3}$ & 215.5 & 231.0 & 593.0 & 476.0 & 20.3 & 20.1 \\
\hline $\mathrm{I}_{4}$ & 204.8 & 219.2 & 544.3 & 518.8 & 17.9 & 18.1 \\
\hline L.S.D. (0.05) & 2.6 & 6.1 & 12.6 & 36.4 & 1.87 & 0.57 \\
\hline \multicolumn{7}{|c|}{ Zinc and Silicon treatments $(F)$} \\
\hline $\mathrm{T}_{1}$ & 213.5 & 227.2 & 691.4 & 638.0 & 20.5 & 21.4 \\
\hline $\mathrm{T}_{2}$ & 222.9 & 238.9 & 657.8 & 628.8 & 19.7 & 21.2 \\
\hline $\mathrm{T}_{3}$ & 232.0 & 246.6 & 733.6 & 679.9 & 21.7 & 22.9 \\
\hline $\mathrm{T}_{4}$ & 205.0 & 218.7 & 603.8 & 565.1 & 19.5 & 19.8 \\
\hline L.S.D. (0.05) & 2.9 & 1.6 & 12.8 & 38.7 & 0.8 & 0.6 \\
\hline \multicolumn{7}{|l|}{ Interactions } \\
\hline IF & 5.9 & 3.2 & 25.6 & 77.4 & 1.7 & 1.2 \\
\hline
\end{tabular}

\subsubsection{Weight of 100-grains (g)}

Results are given in Table 2 clearing that weight of 100-grains (g) significantly affected by irrigation scheduling at every 10,15 and 20 days. Irrigation intervals at every 10,15 and 20 days increased values of this characteristic significantly by $8.8 \%, 3.4 \%$ and $1.3 \%$ in the 2013 season and by $23.1 \%, 11.56 \%$ and $8.9 \%$ in the second season, as compared to irrigation scheduling at every 25 days respectively. Similar results are consistent as compared with those. ${ }^{43,44}$

Results are given in Table 2 which also show that weight of 100-grains (g) significantly affected by foliar spray of zinc and silicon. Application of zinc + silicon, zinc and silicon treatments increased values of this characteristic significantly by $6.1 \%, 5.7 \%$ and $2.1 \%$ in 2013 season and by $11.24 \%, 7.09 \%$ and $4.4 \%$ in the second season, as compared to untreated treatments, respectively. Micronutrients can be applied directly into the soil as well. Soil applied $\mathrm{Zn}$ is effective in enhancing the grain yield whereas $\mathrm{Zn}$ concentration in grain improves via foliar spray of $\mathrm{Zn}$ fertilizer. Based on particular studies. ${ }^{45,42}$ 2.1.5-Biological yield (T/fad.)

Regarding to irrigation treatments, the data revealed in Table 2 that irrigation intervals of 10 days, 15 days and 20 days increased biological yield significantly by $72 \%, 33.9 \%$ and $17.6 \%$ in 2013 season and by $67.1 \%, 45.8$ and $30.8 \%$ in the second season as compared to irrigation scheduling at every 25 days respectively. This may be due to the positive effect of optimum available water on maize biological yield through promoting maize growth. On other hand, many physiological processes in plants are impaired by drought stress including photosynthesis enzyme activity membrane stability pollen viability and ultimately growth. ${ }^{36,40,31}$

Regarding the effect of zinc and silicon treatments on maize biological yield in Table 2. The tabulated data showed clearly that zinc and silicon treatments enhanced significantly values of this characteristic. Use of foliar spray of zinc + silicon and zinc, silicon treatments led to an increase in this characteristic by $10.68 \%, 7.6 \%$ and $21.7 \%$ in 2013 season and by $9.4 \%, 6.1 \%$ and $15.7 \%$ in 2014 as compared to untreated treatment respectively.

The data showed that the highest maize biological yield amounts were as result of practice of foliar spray of zinc + silicon; followed by foliar spray of silicon, zinc treatments. On the contrary the untreated treatments produced the lowest biological yield in the two studied seasons. ${ }^{41,34}$ foliar application of zinc and silicon significantly affected the biological yield of maize crop.

The interaction effect on this characteristic was significant in the two studied seasons. The data showed that shorter irrigation intervals enhanced significantly the effect of foliar spray of zinc and silicon treatments. This might be due to the effect of available water on the transport process in maize.

2.1.6 Grain yield (ard./ fed.)

With regard to irrigation treatments, the results showed that in (Table 2) grain yield values of maize had a significant effect on maize grain yield. The data revealed that irrigation intervals of 10, 15, 20 days significantly increased maize grain yield by $44.39 \%, 21.8 \%$ and $13.6 \%$ in the 2013 season and by $28.2 \%, 15 \%$ and $4.3 \%$ in the second season as compared to irrigation scheduling at every 25 days respectively. This may be attributed to the positive effect of optimum available water through shorter irrigation intervals on number of cells through cell division or on cell size through cell enlargement and turgidity. These results were similar to that findings. ${ }^{40,31}$ 
Relating to the effect of zinc and silicon treatments on maize grain yield, the arranged data in (Table 3) showed clearly that zinc and silicon treatments enhanced significantly values of this characteristic. Use of foliar spray of zinc, silicon and zinc + silicon treatments led to an increase in this characteristic by $19.6 \%, 15.10 \%$ and $35.3 \%$ in 2013 season and by $38.5 \%$, $32 \%$ and $40 \%$ in the second season, as compared to untreated treatment, respectively. Foliar application of $\mathrm{Zn}$ and $\mathrm{Si}$ fertilizers had a positive effect on maize grain yield. ${ }^{46,47}$

Table 2. Means of weight of 100-grains (g), Biological yield $(\mathrm{kg})$ and Grain yield (ard./fed.) of maize crop as effected by irrigation scheduling and foliar spray of zinc and silicon treatments for two growing seasons of 2013 and 2014.

\begin{tabular}{|c|c|c|c|c|c|c|}
\hline \multirow{2}{*}{ Treatments } & \multicolumn{2}{|c|}{ Weight of 100-grains (g) } & \multicolumn{2}{|c|}{ Biological yield (T/fad.) } & \multicolumn{2}{|c|}{ Grain yield (ard./fed.) } \\
\hline & 2013 & 2014 & 2013 & 2014 & 2013 & 2014 \\
\hline \multicolumn{7}{|c|}{ Irrigation scheduling (I) } \\
\hline $\mathrm{I}_{1}$ & 25.8 & 31.0 & 5.8 & 6.1 & 22.2 & 22.0 \\
\hline $\mathrm{I}_{2}$ & 24.5 & 28.1 & 4.5 & 5.3 & 18.7 & 19.7 \\
\hline $\mathrm{I}_{3}$ & 24.0 & 27.5 & 4.0 & 4.7 & 17.4 & 17.9 \\
\hline $\mathrm{I}_{4}$ & 23.7 & 25.2 & 3.4 & 3.6 & 15.3 & 17.1 \\
\hline L.S.D. (0.05) & 0.4 & 0.2 & 0.2 & 0.3 & 0.5 & 0.4 \\
\hline \multicolumn{7}{|c|}{ Zinc and Silicon treatments $(F)$} \\
\hline $\mathrm{T}_{1}$ & 25.0 & 28.3 & 4.3 & 5.0 & 18.7 & 20.8 \\
\hline $\mathrm{T}_{2}$ & 24.2 & 27.6 & 3.9 & 4.8 & 18.0 & 19.8 \\
\hline $\mathrm{T}_{3}$ & 25.1 & 29.4 & 4.7 & 5.3 & 21.2 & 21.0 \\
\hline $\mathrm{T}_{4}$ & 23.7 & 26.5 & 4.2 & 4.6 & 15.6 & 15.0 \\
\hline L.S.D. (0.05) & 0.4 & 0.2 & 0.7 & 0.1 & 0.4 & 0.4 \\
\hline \multicolumn{7}{|l|}{ Interactions } \\
\hline IF & $N . S$ & 0.5 & 0.1 & 0.3 & 0.8 & 0.8 \\
\hline
\end{tabular}

\section{Conclusion}

Generally, from all previous results it can be concluded that the scheduling at every 10 days with spraying zinc + silicon produced the highest yield grain maize yield under the local environment of the Shandaweel region (Upper Egypt).

\section{Experimental}

\subsection{Materials and methods}

The present investigation was carried out at Shandaweel Agricultural Research Station, Sohag, Upper Egypt located at a $26^{\circ} 26^{\prime \prime}$ latitude and $31^{\circ} 68^{\prime \prime}$ during the growing seasons of 2013 and 2014 to study the effect of foliar spray of zinc and silicon treatments on yield, yield components and water relations for maize crop. The experiment design was split- plot design with three repetitions was used in both growing seasons. Water stress treatments were allocated to the main-plots was randomly distributed in the sub plots. The area of each plot was $21 \mathrm{~m}^{2}(3 \times 7 \mathrm{~m})=1 / 200 /$ fed. The soil of the experimented site was clay loam in texture $(24.6 \%$ sand $38.7 \%$ silt and $36.7 \%$ clay). Phosphorus fertilizer was applied at the rate of $23.25 \mathrm{~kg} /$ fed of $\mathrm{P}_{2} \mathrm{O}_{5}$ in the form of mono supper phosphate $\left(15.5 \% \mathrm{P}_{2} \mathrm{O}_{5}\right)$. Phosphorus fertilizer was added at planting time. Nitrogen fertilizer was applied at the rate of $100 \mathrm{~kg} /$ fed in two equal portions in the form of urea $(46.5 \% \mathrm{~N})$. The first portion was added before the first irrigation, while the second portion was applied before the second irrigation. Potassium fertilizer was applied at the rate of $48 \mathrm{~kg} /$ fed of $\mathrm{K}_{2} \mathrm{O}$ in the form of potassium sulfate $\left(48 \% \mathrm{~K}_{2} \mathrm{O}\right)$ and was added into two equal doses at the same times of the nitrogen fertilizer application. Reference evapotranspiration (ETo) values were computed using ETo_calculator_V3.2. ${ }^{48}$ The ETo data also presented in Table 3.

Table 3. Meteorological data for Shandaweel Agric. Res. Station, and reference evapotranspiration (ETo) during the growth season of 2013 .

\begin{tabular}{|c|c|c|c|c|c|c|c|c|c|c|}
\hline \multirow[b]{2}{*}{ Months } & \multicolumn{5}{|c|}{$2018 / 2019$} & \multicolumn{5}{|c|}{$2019 / 2021$} \\
\hline & $\begin{array}{l}\text { Temp } \\
\left({ }^{\circ} \mathrm{C}\right) \\
\text { Max. }\end{array}$ & $\begin{array}{l}\text { ature } \\
\text { Min. }\end{array}$ & $\begin{array}{l}\mathrm{RH} \\
(\%)\end{array}$ & $\begin{array}{l}\mathrm{WS} \\
\mathrm{m} / \mathrm{sec}\end{array}$ & $\begin{array}{l}\text { n } \\
\text { (hours/day) }\end{array}$ & $\begin{array}{l}\text { Temp } \\
\left({ }^{\circ} \mathrm{C}\right) \\
\text { Max. }\end{array}$ & $\begin{array}{l}\text { ature } \\
\text { Min. }\end{array}$ & $\begin{array}{l}\mathrm{RH} \\
(\%)\end{array}$ & $\begin{array}{l}\text { WS } \\
\mathrm{m} / \mathrm{sec}\end{array}$ & $\begin{array}{l}\text { SR } \\
\text { (hours/day) }\end{array}$ \\
\hline June & 38.5 & 22.4 & 34 & 2.2 & 12.3 & 38 & 22 & 34 & 2.3 & 12.3 \\
\hline July & 37.5 & 22.4 & 44 & 1.9 & 12.2 & 35.9 & 21.7 & 38 & 2 & 12.2 \\
\hline August & 37.1 & 22.0 & 46 & 1.9 & 11.9 & 37.2 & 22.9 & 35 & 2 & 11.9 \\
\hline September. & 35.9 & 20.6 & 47 & 2.3 & 10.8 & 34.4 & 21 & 43 & 2.5 & 10.8 \\
\hline Mean & 37.2 & 21.8 & 42.7 & 2.0 & 11.8 & 41.1 & 26.0 & 31.5 & 2.2 & 11.8 \\
\hline
\end{tabular}

$\mathrm{WS}=$ wind speed $\mathrm{m} / \mathrm{sec} ; \mathrm{SR}=$ solar radiation, $\mathrm{MJ} / \mathrm{m}^{2} /$ day, $\mathrm{RH}=$ relative humidity in $\% \mathrm{ETo}=$ evapotranspiration, $\mathrm{mm}$ 
The following characteristics were recorded:

1- Plant height $(\mathrm{cm})$

Ten guarded plants from each entry were selected at maturity an plant height was measured with ammeter rod in centimeters from the ground level to the base of the tassel and the average height was calculated.

2- Flag Leaf area $\left(\mathrm{cm}^{2}\right)$

Flag leaf area was calculated by multiplying the length and maximum width of leaf and multiplying the calculated value by a correction factor of $(0.75) .{ }^{49}$

3-Cob length $(\mathrm{cm})$

Cob length of ten cobs was taken from each plot with the help of measuring tape and then average was taken.

4-Weight of 100-grains ( $g$ )

5-Biological yield (Ton/fed.)

Ten randomly selected whole plants from each treatment were oven-dried at $65^{\circ} \pm 5 \mathrm{C}^{\circ}$ for 48 hours and weighed. Average weight of whole plant including cab as well as grains for each treatment was recorded.

Feddan $=4200 \mathrm{~m}^{2}$

6- Grain yield per plant (ardab)

The grain produced by ten plants used for biological yield was weighed in grams for each treatment. Average grain yield plant was recoded.

Ardab $=140 \mathrm{k} . \mathrm{g}$

A. Irrigation intervals.

$\mathrm{I}_{1}$ - Irrigation every 10 days - with total arrogations (9)

$\mathrm{I}_{2}$ - Irrigation every 15 days - with total arrogations (7)

$\mathrm{I}_{3}$ - Irrigation every 20 days - with total arrogations (6)

$\mathrm{I}_{4}$ - Irrigation every 25 days - with total arrogations (5)

B. Zinc and Silicon treatments.

$\mathrm{T}_{1}$ - Zinc at a rate of $100 \mathrm{mg} / \mathrm{kg}$ on form of Zinc Sulfate $33 \%$ zinc content.

$\mathrm{T}_{2}$ - Silicon at a rate of $100 \mathrm{mg} / \mathrm{kg}$ on form of Silicone Gel.

$\mathrm{T}_{3}$ - Zinc + Silicon $100 \mathrm{mg} / \mathrm{kg}$.

$\mathrm{T}_{4}$ - untreated.

Zinc and Silicon treatments were applied at June 11, 2013 and repeated June 16, 2014 while, harvesting time was October 4, 2013 and October 9, 2014.

Statistical analysis

All data were statistically analyzed according to technique of analysis of variance (ANOVA) as randomized complete block design on split- split plot design as mentioned by means of (MSTAT-C) Computer software package. ${ }^{50,51}$ and Least significant differences (LSD) at 5\% level of probability was used to compare between treatments means. Thanks to this work and the other published papers, the scientific community can make different applications in different fields. ${ }^{52-71}$

\section{References}

1 Abdel-Raheem Sh. A. A., Kamal El-Dean A. M., Hassanien R., El-Sayed M. E. A., and Abd-Ella A. A. (2020) Synthesis and biological activity of 2-((3-Cyano-4,6-distyrylpyridin-2-yl)thio)acetamide and its cyclized form. Alger.j. biosciences, 01 (02) 046-050.

2 Bakhite E. A., Abd-Ella A. A., El-Sayed M. E. A., and Abdel-Raheem Sh. A. A. (2014) Pyridine derivatives as insecticides. Part 1: Synthesis and toxicity of some pyridine derivatives against Cowpea Aphid, Aphis craccivora Koch (Homoptera: Aphididae). J. Agric. Food Chem., 62 (41) 9982-9986.

3 Abdelhamid A. A., Elsaghier A. M. M., Aref S. A., Gad M. A., Ahmed N. A., and Abdel-Raheem Sh. A. A. (2021) Preparation and biological activity evaluation of some benzoylthiourea and benzoylurea compounds. Curr. Chem. Lett., 10 (4) 371-376.

4 Bakhite E. A., Abd-Ella A. A., El-Sayed M. E. A., and Abdel-Raheem Sh. A. A. (2017) Pyridine derivatives as insecticides. Part 2: Synthesis of some piperidinium and morpholiniumcyanopyridinethiolates and their Insecticidal Activity. J. Saud. Chem. Soc., 21 (1) 95-104.

5 Kamal El-Dean A. M., Abd-Ella A. A., Hassanien R., El-Sayed M. E. A., Zaki R. M., and Abdel-Raheem Sh. A. A. (2019) Chemical design and toxicity evaluation of new pyrimidothienotetrahydroisoquinolines as potential insecticidal agents. Toxicol. Rep., 6 (2019) 100-104.

6 Gad M. A., Aref S. A., Abdelhamid A. A., Elwassimy M. M., and Abdel-Raheem Sh. A. A. (2021) Biologically active organic compounds as insect growth regulators (IGRs): introduction, mode of action, and some synthetic methods. Curr. Chem. Lett., 10 (4) 393-412. 
7 Kamal El-Dean A. M., Abd-Ella A. A., Hassanien R., El-Sayed M. E. A., and Abdel-Raheem Sh. A. A. (2019) Design, Synthesis, Characterization, and Insecticidal Bioefficacy Screening of Some New Pyridine Derivatives. ACS Omega, 4 (5) 8406-8412.

8 Abdel-Raheem Sh. A. A., Kamal El-Dean A. M., Zaki R. M., Hassanien R., El-Sayed M. E. A., Sayed M., and Abd-Ella A. A. (2021) Synthesis and toxicological studies on distyryl-substituted heterocyclic insecticides. Eur. Chem. Bull., 10 (4) 225-229.

9 Abdel-Raheem Sh. A. A., Kamal El-Dean A. M., Hassanien R., El-Sayed M. E. A., and Abd-Ella A. A. (2021) Synthesis and characterization of some distyryl-derivatives for agricultural uses. Eur. Chem. Bull., 10 (1) 35-38.

10 Tolba M. S., Sayed M., Abdel-Raheem Sh. A. A., Gaber T. A., Kamal El-Dean A. M., and Ahmed M. (2021) Synthesis and spectral characterization of some new thiazolopyrimidinederivatives. Curr. Chem. Lett., 10 (4) 471 478.

11 Al-Taifi E. A., Abdel-Raheem Sh. A. A., and Bakhite E. A. (2016) Some reactions of 3-cyano-4-(pmethoxyphenyl)-5-oxo-5,6,7,8-tetrahydroquinoline-2(1H)-thione; Synthesis of new tetrahydroquinolines and tetrahydrothieno[2,3-b]quinolines. Assiut University Journal of Chemistry (AUJC), 45 (1) 24-32.

12 Abdel-Raheem Sh. A. A., Kamal El-Dean A. M., Hassanien R., El-Sayed M. E. A., Sayed M., and Abd-Ella A. A. (2021) Synthesis and spectral characterization of selective pyridine compounds as bioactive agents. Curr. Chem. Lett., 10 (3) 255-260.

13 Abdel-Raheem Sh. A. A., Kamal El-Dean A. M., Abdul-Malik M. A., Abd-Ella A. A., Al-Taifi E. A., Hassanien R., El-Sayed M. E. A., Mohamed S. K., Zawam S. A., and Bakhite E. A. (2021) A concise review on some synthetic routes and applications of pyridine scaffold compounds. Curr. Chem. Lett., 10 (4) 337-362.

14 Tolba M. S., Kamal El-Dean A. M., Ahmed M., Hassanien R., Sayed M., Zaki R. M., Mohamed S. K., Zawam S. A., and Abdel-Raheem Sh. A. A. (2022) Synthesis, reactions, and applications of pyrimidine derivatives. Curr. Chem. Lett., 11 (1) 121-138.

15 Abdelhafeez I. A., El-Tohamy S. A., Abdul-Malik M. A., Abdel-Raheem Sh. A. A., and El-Dars F. M. S. (2022) A review on green remediation techniques for hydrocarbons and heavy metals contaminated soil. Curr. Chem. Lett., 11 (1) 43-62.

16 Tolba M. S., Abdul-Malik M. A., Kamal El-Dean A. M., Geies A. A., Radwan Sh. M., Zaki R. M., Sayed M., Mohamed S. K., and Abdel-Raheem Sh. A. A. (2022) An overview on synthesis and reactions of coumarin based compounds. Curr. Chem. Lett.,11 (1) 29-42.

17 Abdel-Raheem Sh. A. A., Kamal El-Dean A. M., Abdul-Malik M. A., Hassanien R., El-Sayed M. E. A., Abd-Ella A. A., Zawam S. A., and Tolba M. S. (2022) Synthesis of new distyrylpyridine analogues bearing amide substructure as effective insecticidal agents. Curr. Chem. Lett., 11 (1) 23-28.

18 Tolba M. S., Sayed M., Kamal El-Dean A. M., Hassanien R., Abdel-Raheem Sh. A. A., and Ahmed M. (2021) Design, synthesis and antimicrobial screening of some new thienopyrimidines. Org. Commun., Accepted Manuscript (DOI: 10.25135/acg.oc.114.2109.2214).

19 Haggag W.M. (2013) Corn Diseases and Management.J.Appl.Sci.Res., 9 (1) 39-43.

20 El FatahH. Y. A.,El Fattah Mohamed E. A., Hassan M. B. A. D., and MohamedK. A. (2015) An Economic Analysis for Maize Market in Egypt. Middle East J., 4 (4) 873-878.

21 Rogers D.H. (1989) Concepts of Irrigation Scheduling. Central Plains Irrigation Short Course Proceedings. Cooperative Extension Service, Kansas State University.

22 Naeem M. (2015) Exploring the role of zinc in maize (Zea mays L.) through soil and foliar application. Univers. J. Agric. Res., 3 (3) 69-75.

23 Noulas C., Tziouvalekas M., and Karyotis T. (2018) Zinc in soils, water and food crops. J. Trace Elem. Med. Biol., 49 252-260.

24 Sharma C. P., Mehrotra S. C., Sharma P. N., and Bisht S. S. (1984) Water stress induced by Zn deficiency in cabbage. Curr. Sci., 53(1) 44-45.

25 Nable R. O., and Webb M. J. (1993) Further evidence that zinc is required throughout the root zone for optimal plant growth and development. Plant Soil, 150 (2)247-253.

26 Epstein E., and Bloom (2005) Mineral nutrition of plants: principles and perspectives, $2^{\text {nd }}$ edn. Sinauer Assoc. Inc, Sunderland, UK.

27 Kojic D., Pajevic S.,Jovanovic-Galovic A., Purac J., Pamer E., Skondric S.,Milovac S., Popovic Z., andGruborLajsic G.(2012) Efficacy of natural aluminosilicates in moderating drought effects on the morphological and physiological parameters of maize plants (Zea mays L.).J. Soil Sci. Plant Nutr., 12(1) 113-123.

28 Hattori T., Sonobe K., Inanaga S., An P., Tsuji W., Araki H., Eneji A. E., and Morita S. (2007) Short term stomatal responses to light intensity changes and osmotic stress in sorghum seedlings raised with and without silicon. Environ. Exp. Bot., 60(2) 177-182.

29 Pei Z.F.,Ming D. F., LiuD., Wan G. L., Geng X .X., GongH.J., andZhou W. J. (2010) Silicon improves the tolerance to water-deficit stress induced by polyethylene glycol in wheat (Triticumaestivum L.) seedlings. J. Plant Growth Regul., 29(1) 106-115.

30 Liang Y., Qirong S., and Zhenguo S. (1999) Effect of silicon on enzyme activity and sodium, potassium and calcium concentration in barley under salt stress. J. Plant Soil, 209(2) 217-224. 
31 Khoshvaghti H., Eskandari-Kordlar M.,andLotfi R. (2013) Responses of morphological characteristic and grain yield of maize cultivars to water stress at reproductive stage. J. Bio. Env. Sci., 3(5)20-24.

32 El-Mahdy A. M. (2015) Effect of irrigation scheduling, planting ridge width and potassium fertilization on maize crop under upper Egypt conditions. MSc thesis .Department of soils and water Faculty of Agriculture Sohag University.

33 Yassin O., Ismail S., Gameh M., Khalil F., and Ahmed E. (2022) Evaluation of chemical composition of roots of three sugar beets varieties growing under different water deficit and harvesting dates in Upper Egypt. Curr. Chem. Lett., 11 (1) 1-10.

34 Amin M., Ahmad R., Ali A., Aslam M., and Lee D.J. (2016) Silicon fertilization improves the maize (Zea mays L.) performance under limited moisture supply. Cereal Res. Commun., 44(1) 172-185.

35 Mahmoud H. M. (2017)Improvement of maize crop (zeamaysl.)by using of nitrogenfertilization and foliar spray of some activators .Ph.D. Thesis, Department of botany and microbiology Faculty of Science Sohag University.

36 Yilmaz E., Akçay S., Gürbüz T., Dagdelen N., and Sezgin F. (2010) Effect of different water stress on the yield and yield components of second crop corn in semiarid climate. J. Food Agric. Environ., 8(1)415-421.

37 Hussein M. M., Balbaa L. K., and Gaballah M. S. (2007) Salicylic acid and salinity effects on growth of maize plants.Res. J. Agric. Biol. Sci., 3 (4) 321-328.

38 Tufail A., Arfan M., Gurmani A. R., Khan, A., and Bano A. (2013) Salicylic acid induced salinity tolerance in maize (Zea mays). Pak. J. Bot., 45 (S1) 75-82.

39 El-Tantawy M. M., Ouda S. A., and KhalilF. A. (2007) Irrigation scheduling for maize grown under middle Egypt conditions.Res. J. Agric. Biol. Sci.,3 (5) 456-462.

40 Kuscu H., and DemirA. O. (2012) Responses of maize to full and limited irrigation at different plant growth stages.Uludă̈̈̈niversitesiZiraatFakültesiDergisi, 26 (2) 15-27.

41 Khalid F., Tahir M., Fiaz N., Nadeem M. A., and GillaniS. M. W. (2013) Hybrid maize response to assorted chelated and non chelated foliar applied zinc rates.J.Agric. Sci. Technol., 9(2)295-309.

42 Muhammad A. (2014) Improving The Performance Of Maize (Zea Mays L) By Silicon Application Under Drought Condition .phd, Thesis University Of Agriculture, Faisalabad. ISO 690.

43 Ahmed H. E. A. (2011) Effect of spatial distribution of plant under different watering regimes on the yield and its components of corn (Zeamayes L.). M.Sc. Thesis, Agron. Dept. Fac. Agric., Assiut Univ., Egypt.

44 Kaman H., Kirda C., and Sesveren S. (2011) Genotypic differences of maize in grain yield response to deficit irrigation. Agric. Water Manag., 98 (5) 801-807.

45 Lauer J.(2006)What happens within the corn plant when drought occurs? Wisconsin Crop Manager. Corn Agronomist, 10(22) 225-228.

46 Chen W., Yao X., Cai K., and Chen J. (2011) Silicon alleviates drought stress of rice plants by improving plant water status, photosynthesis and mineral nutrient absorption. Biol. Trace Elem. Res.,142(1)67-76.

47 Amanullah S. A., Iqbal A., and Fahad S. (2016) Foliar phosphorus and zinc application improve growth and productivity of maize (Zea mays L.) under moisture stress conditions in semi-arid climates. J. Microb. Biochem. Technol., 8 433-439.

48 FAO (Food and Agriculture Organization) (2012) ETo calculator (Version 3.2). Land and Water Division.

49 McKee G. W. (1964) A coefficient for computing leaf area in hybrid corn. J. Agron., 56 (2) 240-241.

50 Gomez K. A., and Gomez A. A. (1984) Statistical procedures for agricultural research. John Wiley and Sons.

51 Steel R. G. D., and Torrie J. H. (1982) Principals and Procedures of Statistics A Biometrical Approach. McGraw Hill Book Company, New York, USA.

52 Saber A. F., Sayed M., Tolba M. S., Kamal A. M., Hassanien R., and Ahmed M. (2021) A Facile Method for Preparation and Evaluation of the Antimicrobial Efficiency of Various Heterocycles Containing Thieno[2,3d]Pyrimidine. Synth. Commun, 51 (3) 398-409.

53 Ahmed M., Sayed M., Saber A. F., Hassanien R., Kamal El-Dean A. M., and Tolba M. S. (2020) Synthesis, Characterization, and Antimicrobial Activity of New Thienopyrimidine Derivatives. Polycycl. Aromat. Compd.,Accepted Manuscript (DOI: 10.1080/10406638.2020.1852587).

54 Kamal El-Dean A. M., Zaki R. M., Radwan S. M., and Saber A. F. (2017) Synthesis, Reactions and Spectral Characterization of Novel Thienopyrazole Derivatives. Eur. Chem. Bull., 6 (12) 550-553.

55 Zaki R. M., Kamal El-Dean A. M., Radwan S. M., and Saber A. F. (2019) Efficient synthesis, reactions and spectral characterization of novel pyrazolo[4',3':4,5] thieno[3,2-d]pyrimidine derivatives and their related heterocycles. Heterocycl. Commun., 25 (1) 39-46.

56 Saber A. F., Zaki R. M., Kamal El-Dean A. M., and Radwan S. M. (2020) Synthesis, reactions and spectral characterization of some new biologically active compounds derived from thieno[2,3-c]pyrazole-5-carboxamide. J. Heterocyclic Chem., 57 (1) 238-247.

57 Yassin O. M., Ismail S., Ali M., Khalil F., and Ahmed E. (2021) OPTIMIZING ROOTS AND SUGAR YIELDS AND WATER USE EFFICIENCY OF DIFFERENT SUGAR BEET VARIETIES GROWN UNDER UPPER EGYPT CONDITIONS USING DEFICIT IRRIGATION AND HARVESTING DATES. Egypt. J. Soil Sci., Accepted Manuscript (DOI: 10.21608/EJSS.2021.105612.1476).

58 Said A. E. A. A., Abd El-Wahab M. M., and Abd El-Aal M. (2014) The catalytic performance of sulfated zirconia in the dehydration of methanol to dimethyl ether. J. Mol. Catal. A Chem., 394 40-47. 
59 Said A. E. A. A., Abd El-Wahab M. M., and Abd El-Aal M. (2016) Catalytic dehydration of methanol to dimethyl ether over nanosized $\mathrm{WO}_{3} / \mathrm{Al}_{2} \mathrm{O}_{3}$ system under inert and oxidative atmosphere. Monatsh. Chem., 147 (9) 1507 1516.

60 Said A. E. A. A., Abd El-Wahab M. M., and Abd El-Aal M. (2016) Effect of $\mathrm{ZrO}_{2}$ on the catalytic performance of nano $\gamma-\mathrm{Al}_{2} \mathrm{O}_{3}$ in dehydration of methanol to dimethyl ether at relatively low temperature. Res. Chem. Intermed., 42 (2) $1537-1556$.

61 Abd El-Aal M., Seto T., Kumita M., Abdelaziz A. A., and Otani Y. (2018) Synthesis of silver nanoparticles film by spark discharge deposition for surface-enhanced Raman scattering. Opt. Mater., 83 263-271.

62 Said A. E. A. A., and Abd El-Aal M. (2018) Effect of different metal sulfate precursors on structural and catalytic performance of zirconia in dehydration of methanol to dimethyl ether. J. Fuel Chem. Technol, 46 (1) 67-74.

63 Said A., and El-Aal M. (2017) Direct dehydrogenation of methanol to anhydrous formaldehyde over $\mathrm{Ag}_{2} \mathrm{O} / \gamma-\mathrm{Al}_{2} \mathrm{O}_{3}$ nanocatalysts at relatively low temperature. Res. Chem. Intermed., 43 (5) 3205-3217.

64 Said A. E. A. A., Aly A. A., Goda M. N., Abd El-Aal M., and Abdelazim M. (2018) Modified sugarcane bagasse with tartaric acid for removal of diazonium blue from aqueous solutions. J. Polym. Environ., 26 (6) 2424-2433.

65 Said A. A., Abd El-Wahab M. M., and Abd El-Aal M. (2016) The role of acid sites in the catalytic performance of tungsten oxide during the dehydration of isopropyl and methyl alcohols. Chem. mater. eng., 213 17-25.

66 Said A. E. A. A., Aly A. A., Goda M. N., Abd El-Aal M., and Abdelazim M. (2020) Adsorptive remediation of Congo Red Dye in aqueous solutions using acid pretreated sugarcane bagasse. J. Polym. Environ., 28 (4) 11291137.

67 El-Aal A., and Seto T. (2020) Surface-enhanced Raman scattering and catalytic activity studies over nanostructured $\mathrm{Au}-\mathrm{Pd}$ alloy films prepared by DC magnetron sputtering. Res. Chem. Intermed., 46 (7) 3741-3756.

68 Abd El-Aal M., Seto T., and Matsuki A. (2020) The effects of operating parameters on the morphology, and the SERS of Cu NPs prepared by spark discharge deposition. Appl. Phys. A, 126 (7) 1-12.

69 Goda M. N., Said A. E. A. A., and Abd El-Aal M. (2020) The catalytic performance of ultrasonically prepared $\mathrm{Cu}_{\mathrm{x}} \mathrm{Co}_{3-\mathrm{x}} \mathrm{O}_{4}$ catalysts towards $\mathrm{CO}$ oxidation at relatively low temperature. Mol. Catal., 494111121.

70 Abd El-Aal M., Mogharbel R. T., Ibrahim A., Almutlaq N., Zoromba M. S., Al-Hossainy A. F., and Ibrahim S. M. (2021) Synthesis, characterization, and photosensitizer applications for dye-based on $\mathrm{ZrO}_{2}$-acriflavine nanocomposite thin film $\left[\mathrm{ZrO}_{2}+\mathrm{ACF}\right]^{\mathrm{C}}$. J. Mol. Struct., 1250131827.

71 El-Aal M. A., and Seto T. (2021) Spark discharge deposition of au/cu nanoparticles for surface-enhanced Raman scattering. Surf. Interface Anal., 53 (9) 824-828.

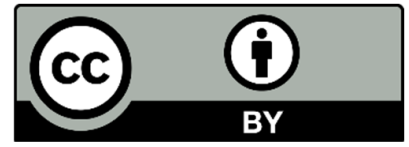

(C) 2022 by the authors; licensee Growing Science, Canada. This is an open access article distributed under the terms and conditions of the Creative Commons Attribution (CC-BY) license (http://creativecommons.org/licenses/by/4.0/). 